\title{
Vegetation structure of wetlands in Eastern Himalayan Highlands of Gasa, Bhutan
}

\author{
Pema Tendar ${ }^{\mathrm{a}, \mathrm{b}, *}$, Kitichate Sridith ${ }^{\mathrm{a}}$ \\ ${ }^{a}$ Department of Biology, Faculty of Science, Prince of Songkla University, Songkhla 90110 Thailand \\ b Department of Science, Chundu Armed Forces Public School, Ministry of Education, Haa 15004 Bhutan
}

*Corresponding author, e-mail: pematendar@gmail.com

Received 19 Mar 2020

Accepted 2 Nov 2020

\begin{abstract}
The study was conducted on the unexplored wetland vegetation of the eastern Himalayan highlands of Gasa District, Northern Bhutan. A random quadrat sampling of $1 \times 1 \mathrm{~m}^{2}$ method was used to assess the presenceabsence of species, including shrubs, trees, mosses, ferns, and climbers, that were occurring adjacent to plots. Altogether, 201 taxa from 81 families, distributed in 149 genera, were recorded. Among the total species, 6 bryophytes, 20 monilophytes, 2 gymnosperms, and 173 angiosperms species were found. The most abundant life forms represented were herbaceous (62\%) and shrub (29\%), followed by tree (7\%) and climber (2\%). The four unique vegetation structure (represented in schematic profile diagrams) of habitats: fresh water meadow, seasonally flooded basin of flat, shallow fresh marsh, and poor fen, were found. The study suggests protecting ecotone (a transition zone between the wetland and surrounding uplands) as part of the measures to protect wetlands and their vegetation in the Himalayas.
\end{abstract}

KEYWORDS: wetland, vegetation structure, schematic profile diagram, ecotone

\section{INTRODUCTION}

Wetlands are biologically diverse ecosystems that provide critical habitat to a wide range of plants and animals in the world. The ability of plants to inhabit wet places and represent a various grouping of species with different ecological tolerances, adaptations, and life history strategies that allows their existence in flooded or saturated soils are termed as wetland plants [1]. Further, wetland plants are defined by their ability to grow on a substrate or in water that is periodically lacking in oxygen due to excessive water content [2].

Wetland plants are interesting as they have unique evolutionary tactics for coping with life in a flooded environment and help us to identify the boundaries of a wetland [1]. These wetland plants occur mostly in heath forests, forest fragments and bottomlands surrounded by upland forests. These small wetland habitats provide unique combination of upland forest species and wetland specialist species with high plant diversity [3]. Further, Kent and Coker [4] claimed that these marginal species from the adjacent areas around the habitat or community type can greatly increase species diversity. Also, Van der Maarel [5], emphasized that transactional or ecotone areas are of great interest ecologically and deserve more attention in research.
The Himalayan Region is known as one of the worldwide significant biodiversity hotspots due to rich repository of native and endemic biodiversity [6]. As part of Eastern Himalaya, Flora of Bhutan documented 5603 species of vascular plants out of which approximately 94 percent are native species [7]. Eastern Himalaya, including Bhutan, is also a remarkable repository for fauna and flora [8,9]. Further, National Biodiversity Centre [10] recorded 144 species as currently endemic to Bhutan Himalaya, which is a remarkable diversity of endemism considering the size of the country. Of the total species recorded (144), about $49 \%$ (71) are incredibly recorded in Jigme Dorji National Park (JDNP). Hence, in order to ensure their conservation and management, study of the plants in such environments should be considered of key importance. Moreover, several natural habitats are at risk and the species within them experience potential extinction [11]. There is also massive habitat loss in the buffer zone that results in species destructions [12] and positioning numerous wetland species on threatened and endangered species lists. The lack of International Union for Conservation of Nature (IUCN) assessment further makes it challenging to understand the status of native species of national concern [7]. There was also no comprehensive study on the vegetation structure of 
(a)

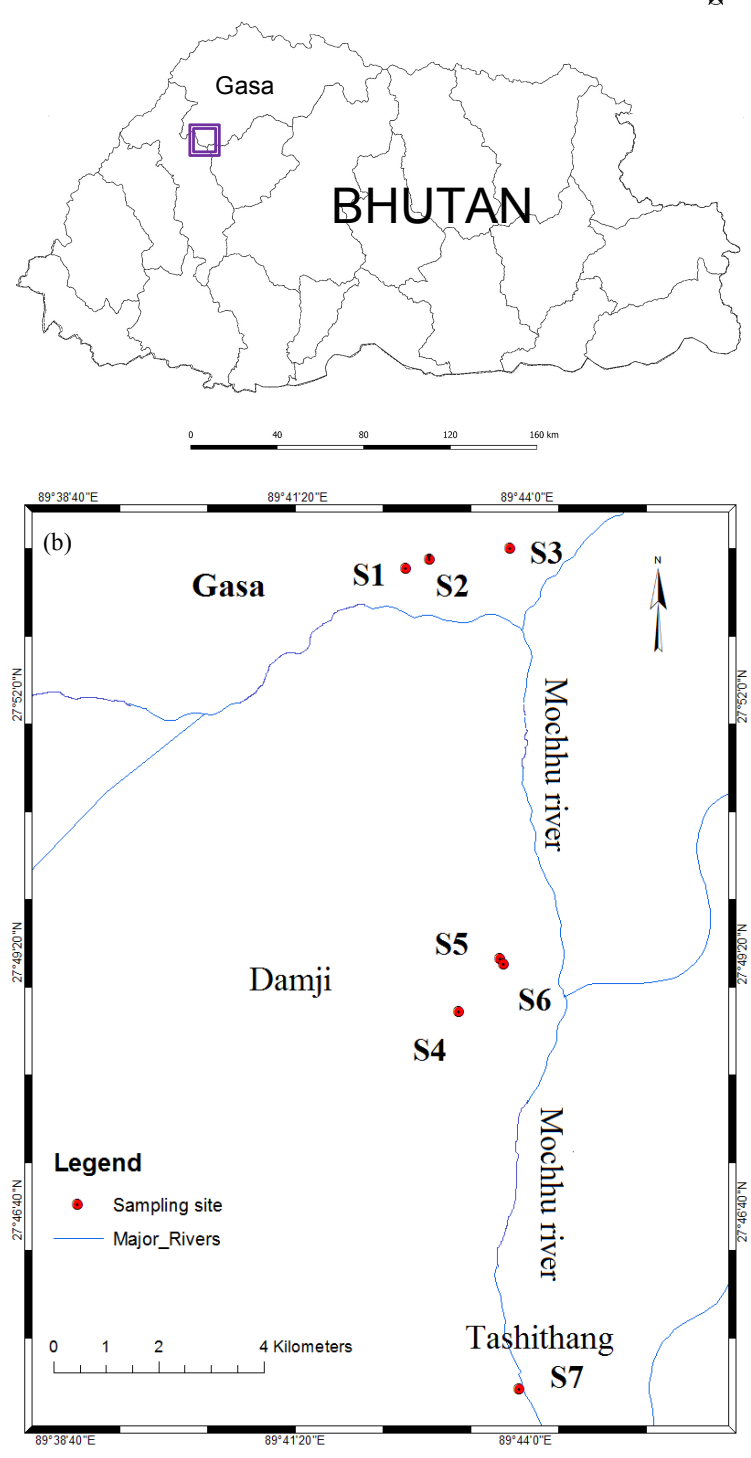

Fig. 1 Gasa, the location for this study is indicated in Bhutan map diagram (a); whereas, S1, Gasa1; S2, Gasa2; S3, Gasa3; S4, Damji1; S5, Damji2; S6, Damji3; S7, Tashithang (black circle dots) (b) were represented for sampling sites.

wetlands in Gasa, a part of JDNP, and therefore, objectives of the study were to: (1) provide a checklist of the freshwater wetland plants and (2) describe the structure of habitats in highland wetlands of Gasa, Bhutan.

\section{MATERIALS AND METHODS}

\section{Study area}

The study was conducted in Gasa, a part of JDNP, along the $28 \mathrm{~km}$ road stretch on the left side of Mochu River, that lies between $27^{\circ} 43^{\prime} 05^{\prime \prime}$ $28^{\circ} 09^{\prime} 35^{\prime \prime} \mathrm{N}$ (latitudes) and $89^{\circ} 45^{\prime} 33^{\prime \prime}-89^{\circ} 38^{\prime} 44^{\prime \prime} \mathrm{E}$ (longitude) (Fig. 1). The elevation ranges from 1597 to $2538 \mathrm{~m}$ above sea level. The vegetation type in the region is warm temperate forest [13]. The area experiences short summer and long winter with the mean annual rainfall over a decade (20082017) ranged from 498 to $1824 \mathrm{~mm}$ and heavy rainfall in the month of July to August. Similarly, air temperature of the region ranges from $5-16^{\circ} \mathrm{C}$ [14]. The study areas were mostly occurred in the bottomlands, slopes, and forest fragments surrounded by natural vegetation.

\section{Data collections}

Floristic inventory was done almost every month (February to November 2018) to assess the status and flowering seasons for detailed identification of plants. All collected plant materials were prepared according to the guidelines of herbarium handbook [15]. A random quadrat sampling of $1 \times 1 \mathrm{~m}^{2}$ method was used to assess the presence-absence of species. The number of quadrat samples taken from each site varied due to occurrence of different sizes in wetlands. The vegetation of each quadrat sample was identified in the field and recorded all species in that plot, including the ones (shrubs, trees, mosses, ferns, and climbers) occurring adjacent to the plots, in order to acquire the comprehensive list of plants within the wetlands. The life form group was followed with slight modifications [16]. The classification of wetland habitats according to Smith [17] was followed and later identified habitats [18] were represented in the form of schematic profile diagram to represent the vegetation structure in the region. Vegetation profile of representative sites (X and Yaxes) were drawn accounting the measurement of plant height [19] and length of site (measured using $100 \mathrm{~m}$ measuring tape). A graded bamboo stick was used to measure the depth of water in each site. All collected specimens were taken to the National Biodiversity Center, Thimphu, Bhutan for confirmation; and unknown species were identified in consultation with specialized literature and specialists in different taxonomic groups. Floras of Bhutan (including a record of plants from Sikkim [20-23], a record of plants from Sikkim and Darjeeling [24-26], the grasses of Bhutan [27], the orchids of Bhutan [28], 

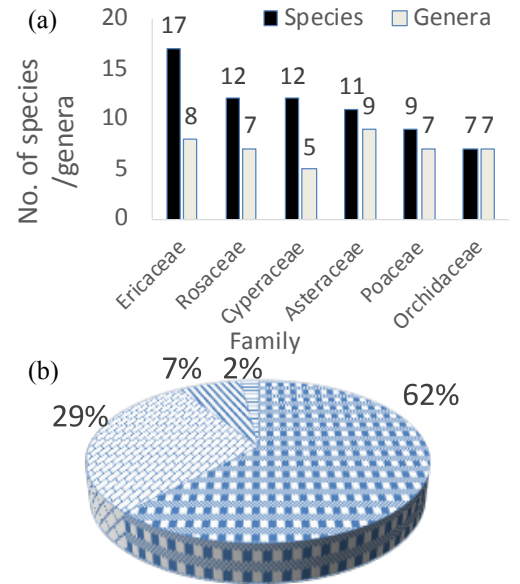

$\square$ Herb $\square$ Shrub $\square$ Tree $\square$ Climber

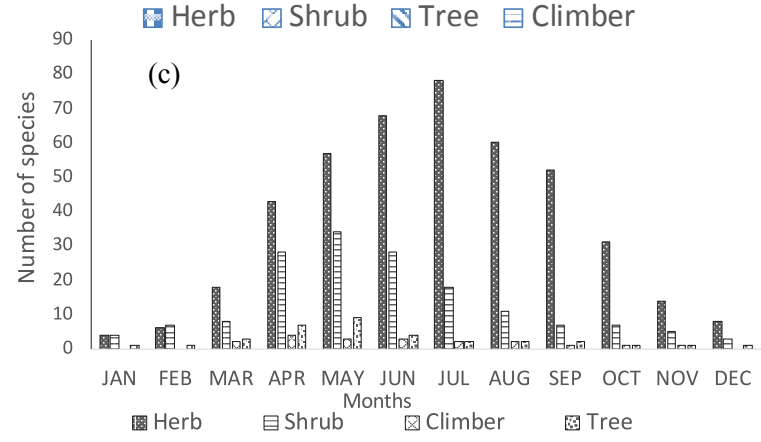

Fig. 2 Vegetation diversity structures found at Highland wetlands of Gasa were as follows: (a) proportion of six dominant families with different genus and species, (b) proportion of life forms of herb, shrub, climber and tree, and (c) growing seasons year around of different life forms.

and eFloras of China [29]) were followed for the identification of species and families. The species' names and families were updated in an online data base, the Tropicos. The Angiosperm Phylogeny Group IV classification was followed for the classification of families [30]. All the voucher specimens were deposited at the Herbarium, National Biodiversity Center, Thimphu, Bhutan.

\section{RESULTS}

\section{Floristic composition}

A total of 201 species of plants, distributed in 149 genera and 81 families, of which 55\% (111 species) were within quadrat $\left(1 \times 1 \mathrm{~m}^{2}\right)$ sampling plots (226) and 45\% (90 species) occurred adjacent to sampling plots (Tables 1 and S1). Among the total species, 6 species of bryophytes, 20 species of monilophytes, 2 species of gymnosperms, and 173 species of angiosperms (125 eudicots, 4 mag- noliids, and 44 monocots) are presented in Table 1. The three most dominant families of eudicots were Ericaceae (17 species), Rosaceae (12 species), and Asteraceae (11 species) that comprised 8.5\%, 6.0\%, and $5.5 \%$ of the total flora, respectively. The three most diverse group of monocots were Cyperaceae (12 species), Poaceae (9 species), and Orchidaceae (7 species) that consisted of $6.0 \%, 4.5 \%$, and $3.5 \%$ of the total recorded species, respectively. Dryopteridaceae (4 species, 2.0\%), Polypodiaceae (4 species, $2.0 \%$ ), and Seleginellaceae (3 species, $1.5 \%)$ were the largest families represented in the group in monilophytes. In bryophytes group, single species was represented in each family. In the group of gymnosperms, Pinaceae and Taxaceae represented one species each. The six most dominant families are Ericaceae, Rosaceae, Cyperaceae, Asteraceae, Poaceae, and Orchidaceae (Fig. 2a). Altogether, they comprise about $34 \%$ of the total number of species in the studied areas. In this study, every species recorded is provided with taxonomic group, lifeform, flowering season, and voucher number (Table S2).

\section{Lifeform and flowering seasons}

The herbaceous and shrub lifeform were the most abundant species, recorded with $62 \%$ (125 species) and $29 \%$ (59 species), respectively; while the trees and climbers were least represented, at 7\% (13 species) and 2\% (4 species), respectively (Fig. 2b). The flowering for herbs mostly occurred in April to September, but peaked in July. The shrubs flowered mostly in April to July with the peak month in May. May and April months were the peak flowering seasons for trees and climbers, respectively (Fig. 2c).

\section{The habitat types and vegetation}

Based on the topographic features and vegetation of the wetlands, four most characteristic habitat types inhabited by plants were identified (Figs. 3 and 4).

Shallow fresh marsh was usually located near small streams and bottomlands. There is only one aquatic species, Potamogeton crispus L. occurred in such open pools (Fig. 3a). The characteristic species, i.e. Enkianthus deflexus (Griff.) C.K. Schneid., Persicaria nepalensis (Meisn.) H. Gross and Rhododendron dalhousieae var. rhabdotum (Balf. f. \& R.E. Cooper) Cullen, were prominently found adjacent to the habitat. The Acorus calamus L. was abundant; and this characteristic species created a mat of vegetation that allowed small streams to run through channeling underneath. These channels 
Table 1 Results showing the floristic composition in wetlands of Gasa.

\begin{tabular}{lccccccc}
\hline Taxonomic group & Families & Genera & Species & Trees & Shrubs & Herbs & Climbers \\
\hline Angiosperms & 61 & 126 & 173 & 11 & 59 & 99 & 4 \\
Gymnosperms & 2 & 2 & 2 & 2 & - & - & - \\
Bryophytes & 6 & 6 & 6 & - & - & 6 & - \\
Monilophytes & 12 & 15 & 20 & - & - & 20 & - \\
\hline Total & 81 & 149 & 201 & 13 & 59 & 125 & 4 \\
\hline
\end{tabular}
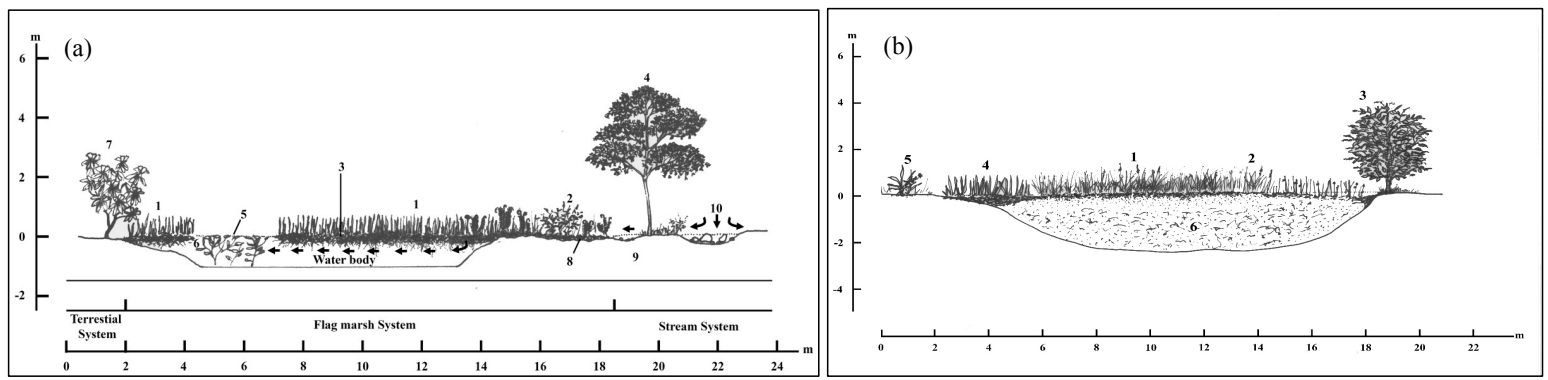

Fig. 3 Schematic profile diagram at Gasa. (a) Flag marsh vegetation: 1. Acorus calamus, 2. Persicaria nepalensis, 3. firm mat of flag marsh vegetation with water channel underneath, 4. Enkianthus deflexus, 5. open pool with aquatic vegetation, 6. Potamogeton crispus, 7. Rhododendron dalhousieae var. rhabdotum, 8. soil (organic matter) with firm mat of sweet flags' spreading rhizomes, 9. soil (loamy sand) with arrow showing the movement of underground water, and 10. channeled stream water and its movement (arrow showing its flow direction). (b) Carex diandra vegetation: 1. Carex diandra, 2. Schoenoplectus mucronatus, 3. Lyonia ovalifolia, 4. Acorus calamus, 5. Cymbidium iridioides, and 6. moderately decomposed sedge peat.

run on the side of the habitat ensuring minimal entry into the surface of habitat. During rainy seasons, these habitats were partially submerged, but well drained within few weeks.

Seasonally flooded basin of flat usually occurred in open bottomlands with floating mats dominated by Carex diandra Schrank. In fact, this habitat usually occurred in narrow zone where there is water underneath. This characteristic species was found only in the wettest part of this filled basin including Schoenoplectus mucronatus (L.) Palla (Fig. 3b). The Acorus calamus L. vegetation inhabited next to this C. diandra Schrank vegetation, followed by Lyonia ovalifolia (Wall.) Drude, Malus baccata (L.) Borkh, and Enkianthus deflexus (Griff.) C.K. Schneid towards edge of forest. The epiphytic orchid, Cymbid-
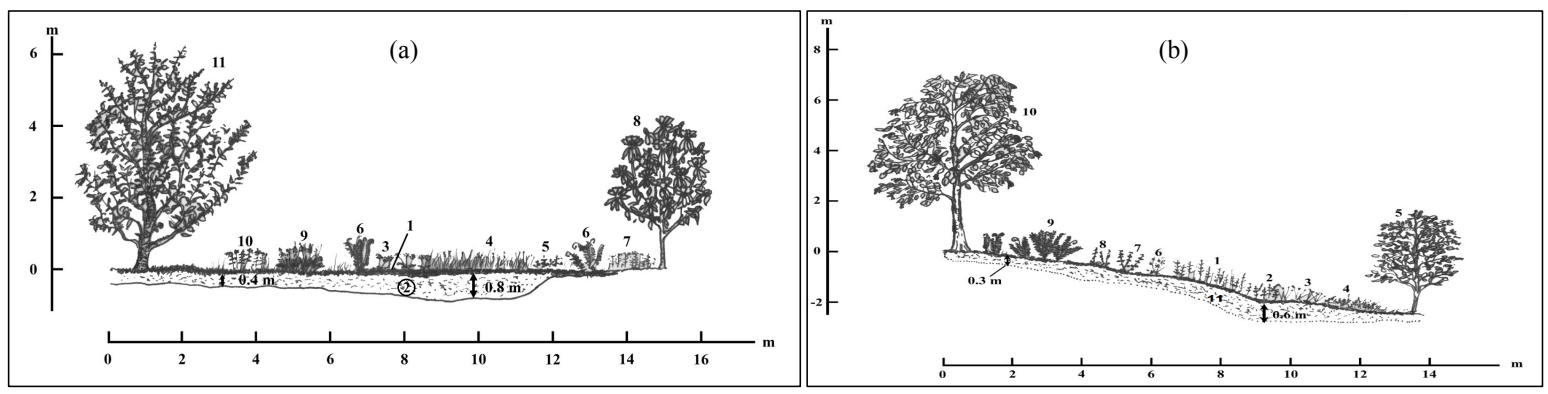

Fig. 4 Schematic profile diagram at Gasa. (a) Poor fen vegetation: 1. Sphagnum palustre, 2. undecomposed moss peat, 3. Primula denticulata, 4. Carex capillacea, 5. Gentiana cephalodes, 6. Osmunda japonica, 7. Anaphalis margaritacea, 8. Rhododendron arboreum, 9. Luzula effusa, 10. Halenia elliptica, and 11. Malus baccata. (b) Fresh water meadow: 1. Equisetum ramosissimum, 2. Neanotis calycina, 3. Xyris capensis var. schoenoides, 4. Galium aparine, 5. Lyonia villosa, 6. Ixeridium beauverdianum, 7. Pedicularis gracilis subsp. stricta, 8. Spiranthes sinensis, 9. Matteuccia struthiopteris, 10. Alnus nepalensis, and 11. wet soil with small sedge peat. 
ium iridioides D. Don, was also inhabited on lifeless tree at the edge of the habitat.

Poor fen habitat occurred in open and forest fragments of slightly higher elevations (2433 m and above). Some patches of Sphagnum palustre L. vegetation were confined to this habitat and a thick layer of undecomposed peat within this vegetation was also prominent. Another characteristic species inhabited was Osmunda japonica Thunb. that occurred in some patches. The ericaceous shrubs were prominent in such habitats, e.g. Rhododendron arboreum Sm. and Malus baccata (L.) Borkh. (Fig. 4a). The climber species, Holboellia latifolia Wall., was also recorded on the M. baccata (L.) Borkh. shrub that occurred in the open habitat. This vegetation was usually influenced by precipitation in the area lacking groundwater and upstream components.

Fresh water meadow usually occurred on the slopes, open heath forests and, sometimes, even in fallow lands. This habitat usually has no standing water but remained waterlogged most of the year. The diverse and characteristic species, such as Lyonia villosa (Wall. ex C.B. Clarke) Hand.Mazz., Spiranthes sinensis (Pers.) Ames, Matteuccia struthiopteris (L.) Tod. and Alnus nepalensis D. Don, are inhabited in this habitat. Mostly the characteristic species of herbs in this habitat are stunted (Fig. 4b).

\section{DISCUSSION}

Most of represented families differed within Himalayan Regions. The topmost dominant family, Ericaceae with 17 species, comprised $21 \%$ of total species (81 species) in the country [23]. However, this family was not even appeared in top ten dominant families in the Western and Eastern Himalayas [31] indicating that this family occurred mostly in the wetlands and its surroundings (ecotone). These ericaceous shrubs may be acid loving plants since they are mostly inhabited in the acidic soil/peat of wetlands [32]. Therefore, the diversity of ericaceous shrubs is high and topped the family representation in the wetlands (Fig. 2a). This result is limited to present study and may not represent the actual status of ericaceous plant diversity in the country. Hence further study on quantitative assessment of wetland plants are required to further confirm this result in the country and the region. The second dominant family was Rosaceae (12 species) represented $8.5 \%$ of total species (141 species) of the flora of Bhutan. However, in the Eastern and Western Himalayas, the family dominance stood at eighth position and might be changed if similar studies are undertaken there. The third dominant family is Cyperaceae (12 species) which was fourth and fifth in the Eastern and Western Himalayas, respectively. This family has close affinity with the flora of western region and the family may have represented mostly from wetlands (Fig. 2a). Asteraceae (11 species) represented fourth position in the Eastern Himalayas and, therefore, their suitable habitats could be in wetlands of lower montane areas in the region. In the Western Himalayas, this family represented second position and may indicate diverse habitat preferences. However, this family included one invasive species, Ageratina adenophora (Spreng.) R.M. King \& H. Rob. which is almost a threat to wetlands; and habitat loss may occur, thereby, threatening many wetland species [7]. Fortunately, this species occurred only in one site due to anthropogenic disturbances since being closed to road and human settlement. Therefore, understanding plants and its habitats may be first step in combating species loses. Orchidaceae presented sixth position, which is topmost dominant family in the country as well as in the Eastern Himalayas (Fig. 2a). These orchids represented 1.5\% (7 species) of the total orchids (469 species) in the country $[28,33]$. The wetland habitats have favored these epiphytic and ground orchids to inhabit in and around the wetlands, thereby diversifying species in the wetlands. Amongst the least represented families, Potamogetonaceae showed unique species in the region. Potamogeton crispus L. is only aquatic plant represented in the wetlands and inhabited in small pools and running stream. However, this species was found frequent in Western Himalaya [34]. Altogether, the diversity of species in the wetlands represented $14 \%$ of the total flora in Jigme Dorji National Park and 3.6\% of flora of Bhutan (Table S2).

The proportion of abundant species in the lifeform group varied within the region. The proportion order of abundant species, i.e. herbs (62\%), shrubs (29\%), trees (7\%), and climbers (2\%) were recorded with similar pattern in the region (Fig. 2b). However, proportion of herbs and shrubs species were slightly higher compared to other parts of the country $[16,35]$ and the Western Himalaya [36] that may be an indicator that the species representations are from wetlands including ecotone. Similarly, the proportion of trees and climbers under study are two to three folds lesser, as these wetlands usually are located at edge or open forest fragments, hence less trees and climbers (Fig. 2b).

The flowering seasons of lifeform groups also 
varied in the wetlands. The peak flowering seasons for herbs, shrubs and trees, and climbers were in July, May and April months, respectively (Fig. 2c). These data may be useful for the science education programs (e.g. excursions) in schools and colleges to learn about pollination and floral ecology of diverse wetland plants.

The vegetation structure of habitat indicates its uniqueness in supporting the diverse species in each habitat. The species represented in the figures are the ones that are unique and abundant in such habitats. These species differed among habitats may be due to different microhabitats supporting such unique species. Therefore, these natural vegetation profile clearly displayed various structures of the unique vegetation and species composition in each habitat (Figs. 3 and 4).

The only submerged species, Potamogeton crispus L., occurred only in Shallow fresh marsh (Fig. 3a) and, in open pools due to light reaching into the bottom (depth of approximately 1 to $1.5 \mathrm{~m}$ ) of habitat. The continuous discharge of water from bottom of the pools indicated water table (arrow showing flow of water towards pool) connected by small stream flowing under the firm mat vegetation. This species also occurred in flowing water towards south of the pools indicating undisturbed vegetation. However, there were no ponds nor proper drainage for flowing water to support this species in other three sites of this type of habitat. The abundant and characteristic species, Acorus calamus L., had created a mat (0.1-0.4 m depth of peat and soil) of vegetation and the small stream flowing underneath the mat vegetation at few points (about 4 to $6 \mathrm{~m}$ distance) (Fig. 3a). This channel may minimize entry of excess water into the surface of habitat. The characteristic species, i.e. Enkianthus deflexus (Griff.) C.K. Schneid., Persicaria nepalensis (Meisn.) H. Gross, and Rhododendron dalhousieae var. rhabdotum (Balf. f. \& R.E. Cooper) Cullen may have added local species richness in the wetlands. Therefore, such intact pools, stream running underneath of mat vegetation and adjacent (ecotone) vegetation may have supported diverse species in such habitats (Fig. 3a).

The seasonally flooded basin of flat habitat occurred where there is permanent water underneath that supported the floating mats (Carex diandra Schrank.) vegetation indicating specific habitat (narrow zone) (Fig. 3b). This characteristic species was found only in the wettest part of this filled basin with the depth of about 2 to 2.5 meters of moderately decomposed sedge peat. The Acorus calamus $\mathrm{L}$. and other species inhabited towards edge of forest next to C. diandra Schrank vegetation, which may represent an ecotone for this habitat (Fig. 3b). Therefore, supported unique species may be available due to its differences in availability of water underneath, open space, and flat surface of habitats.

The poor fen habitat occurred slightly at higher elevations with thick layer of partial or undecomposed peat (about 0.4-0.8 m) of Sphagnum palustre L., which indicates the slower biological activity because of cold temperature (Fig. 4a). The ericaceous shrubs, Rhododendron arboreum Sm. and Malus baccata (L.) Borkh., were characteristic species in such habitat; and that may indicate unique composition of species. The Osmunda japonica Thunb. including ericaceous shrubs occurred in some patches that may indicate territorializing the wetland habitats and supporting diverse species.

The fresh water meadow usually occurred on the slopes and open heath forests indicating no standing water during growing seasons. Due to this unique habitat, diverse species of herbs, shrub and trees are supported, including characteristic species such as Spiranthes sinensis (Pers.) Ames, Matteuccia struthiopteris (L.) Tod., Lyonia villosa (Wall. ex C.B. Clarke) Hand.-Mazz. and Alnus nepalensis D. Don (Fig. 4b). The characteristic species of herbs in this habitat, such as Equisetum ramosissimum Desf., Neanotis calycina (Wall. ex Hook. f.) W. H. Lewis, Galium aparine L., Ixeridium beauverdianum (H. Lév.) Spring., Pedicularis gracilis subsp. stricta (Prain) P.C. Tsoong, and Spiranthes sinensis (Pers.) Ames, are stunted. This may be due to less nutrients in soil and anthropogenic disturbances since they are located close to human settlements.

\section{CONCLUSION}

Wetland study has seen few important implications for conservation and management of biodiversity. Firstly, it shows that wetlands within the heath forests, forest fragments and bottomlands are truly a valuable resource for the conservation of plant diversity due to presence of large number of local species richness and several local rare species. In addition, high conservation priority could be given for wetlands with indicator species in the sites. These small wetland habitats supported both upland forest species and wetland species, which upland landscapes would not support the wetland species. Therefore, such small wetland habitats deserve protection. Secondly, to protect these wetlands, ecotone should also be considered to keep 
the wetlands functionally intact. The study suggests protecting ecotone as part of the measures to protect wetlands. Lastly, the lack of IUCN assessment makes it challenging to understand the status of the native species of national/international concern. Therefore, species-based conservation action plans are required to improve their conservation status in the country.

\section{Appendix A. Supplementary data}

Supplementary data associated with this article can be found at http://dx.doi.org/10.2306/ scienceasia1513-1874.2021.007.

Acknowledgements: The Graduate School of Prince of Songkla University, Hat Yai, Songkhla, Thailand's Education Hub for ASEAN Countries and Center of Excellence on Biodiversity (BDC), Office of Higher Education Commission (BDC-PG3-160016), Ministry of Higher Education, Science, Research and Innovation, Thailand supported this research. Authors would like to extend appreciation to Mr. Kezang Tobgay, Herbarium, National Biodiversity Centre for helping in authentication of specimens, Mr. Sangay Namgay, teacher of Wanakha Centre School, Paro for preparing schematic profile diagrams, Mr. Tshering Dendup (CiD-1090500086), teacher for preparing our study map and Mr. Sangay Tenzin (EiD-20190113354), teacher of CAFPS, Haa for his field assistance during sample collections.

\section{REFERENCES}

1. Cronk JK, Fennessy MS (2001) Wetland Plants Biology and Ecology, Lewis Publishers, Boca Raton, London.

2. Cowardin LM, Carter V, Golet FC, LaRoe ET (1979) Classification of Wetlands and Deepwater Habitats of the United States, US Department of the Interior, Fish and Wildlife Service, Washington DC, USA.

3. Flinn KM, Lechowicz MJ, Waterway MJ (2008) Plant species diversity and composition of wetlands within an upland forest. Am J Bot 95, 1216-1224.

4. Kent M, Coker P (1992) Vegetation Description and Analysis: A Practical Approach, John Wiley \& Sons Ltd, Chichester.

5. Van der Maarel E (1990) Ecotones and ecoclines are different. $J$ Vegetat Sci 1, 135-138.

6. Dar JA, Sundarapandian S (2016) Patterns of plant diversity in seven temperate forest types of Western Himalaya, India. J Asia Pac Biodivers 9, 280-292.

7. National Biodiversity Centre (2014) National Biodiversity Strategies and Action Plan of Bhutan, Ministry of Agriculture and Forests, Bhutan.

8. Kandel P, Gurung J, Chettri N, Ning W, Sharma E (2016) Biodiversity research trends and gap analysis from a transboundary landscape, Eastern Himalayas. $J$ Asia Pac Biodivers 9, 1-10.

9. Namgay S, Sridith K (2020) Distribution pattern of the genus Rhododendron in Bhutan Himalayan range. ScienceAsia 46, 429-435.

10. National Biodiversity Centre (2015) Plants Endemic to Bhutan Himalaya, Ministry of Agriculture and Forests, Thimphu, Bhutan.

11. Bajpai O, Kumar A, Srivastav AK, Kushwaha AK, Pandey J, Chaudhary LB (2015) Tree species of the Himalayan Terai region of Uttar Pradesh, India. Check List 11, 1-15.

12. Bora A, Bhattacharyya D (2017) Phytodiversity of Barail wildlife sanctuary, Assam, India: field-based observations-I. Trees and lianas. Check List 13, 1037-1053.

13. Ohsawa M (1987) Life Zone Ecology of the Bhutan Himalaya, Chiba University, Japan.

14. National Center for Hydrology and Meteorology (2018) National Center for Hydrology and Meteorology, Thimphu, Bhutan.

15. Foreman L, Bridson D (1998) The Herbarium Handbook, 3rd edn, Whitstable Litho Printers Ltd, London.

16. Jamtsho T, Sridith K (2017) Species composition of the vegetation along the Sherichhu river, lower montane area of Eastern Bhutan. Songklanakarin $J$ Sci Technol 39, 303-316.

17. Smith RL (1966) Ecology and Field Biology, Harper and Row, New York.

18. Tendar P, Cooper DJ, Sridith K (2020) Wetland plant communities of the Eastern Himalayan Highlands in Northern Bhutan. Wetlands.

19. Tobgye T (2015) Vegetation structure and vascular plant diversity of lower montane forest at Korila, Mongar, eastern Bhutan. MSc thesis, Prince of Songkla Univ, Thailand.

20. Grierson AJC, Long DG (1983) Flora of Bhutan, vol 1(1), Royal Botanic Garden, Edinburgh.

21. Grierson AJC, Long DG (1984) Flora of Bhutan, vol 1(2), Royal Botanic Garden, Edinburgh.

22. Grierson, AJC, Long DG (1987) Flora of Bhutan, vol 1(3), Royal Botanic Garden, Edinburgh.

23. Grierson AJC, Long DG (1991) Flora of Bhutan, vol 2(1), Royal Botanic Garden, Edinburgh.

24. Grierson AJC, Long DG (1999) Flora of Bhutan, vol 2(2), Royal Botanic Garden, Edinburgh.

25. Grierson AJC, Long DG (2001) Flora of Bhutan, vol 2(3), Royal Botanic Garden, Edinburgh.

26. Noltie HJ (1994) Flora of Bhutan, vol 3(1), Royal Botanic Garden, Edinburgh.

27. Noltie HJ (2000) Flora of Bhutan, vol 3(2), Royal Botanic Garden, Edinburgh.

28. Pearce NR, Cribb PJ (2002) Flora of Bhutan, vol 3(3), Royal Botanic Garden, Edinburgh.

29. eFloras (2008) Flora of China, Missouri Botanical Garden, St. Louis, MO \& Harvard University Herbaria, Cambridge, MA. 
30. Angiosperm Phylogeny Group (2016) An update of the Angiosperm Phylogeny group classification for the orders and families of flowering plants: APG IV. Bot J Linn Soc 181, 1-20.

31. Chawla A, Parkash O, Varun Sharma V, Rajkumar S, Lal B, Gopichand, Singh RD, Thukral AK (2012) Vascular plants, Kinnaur, Himachal Pradesh, India. Check List 8, 321-348.

32. Richardson JL, Vepraskas MJ (2001) Wetland Soils: Genesis, Hydrology, Landscapes, and Classification, Lewis Publishers, Boca Raton, London.

33. National Biodiversity Centre (2017) A Century of
New Orchid Records in Bhutan, Kuensel Corporation Limited, Thimphu, Bhutan.

34. Adhikari BS, Babu MM (2008) Floral diversity of Baanganga Wetland, Uttarakhand, India. Check List 4, 279-290.

35. Tobgye T, Sridith K (2018) Preliminary notes on distribution of Himalayan plant elements: A case study from Eastern Bhutan. Songklanakarin J Sci Technol 40, 370-378.

36. Pal DK, Kumar A, Dutt B (2014) Floristic diversity of Theog Forest Division, Himachal Pradesh, Western Himalaya. Check List 10, 1083-1103. 


\section{Appendix A. Supplementary data}

Table S1 Total plots sampled and species recorded (in $1 \times 1 \mathrm{~m}^{2}$ plot and adjacent plot) in each site.

\begin{tabular}{lccccccrr}
\hline Site/site code & $\begin{array}{c}\text { Gasa1 } \\
\text { (S1) }\end{array}$ & $\begin{array}{c}\text { Gasa2 } \\
\text { (S2) }\end{array}$ & $\begin{array}{c}\text { Gasa3 } \\
\text { (S3) }\end{array}$ & $\begin{array}{c}\text { Damji1 } \\
\text { (S4) }\end{array}$ & $\begin{array}{c}\text { Damji2 } \\
\text { (S5) }\end{array}$ & $\begin{array}{c}\text { Damji3 } \\
\text { (S6) }\end{array}$ & $\begin{array}{c}\text { Tashithang } \\
\text { (S7) }\end{array}$ & Total \\
\hline Plots/site & 44 & 31 & 45 & 48 & 22 & 18 & 18 & 226 \\
Species/site & 45 & 33 & 37 & 40 & 29 & 32 & & 34 \\
\hline \multicolumn{2}{l}{ Species recorded from 7 sites (plot) } \\
\multicolumn{2}{l}{ Species recorded from adjacent plots (including shrub, liana, fern and tree) } \\
\hline
\end{tabular}

Table S2 List of wetland plant species recorded with taxonomic group, lifeform, flowering seasons and voucher number in Gasa, Bhutan. Species in the list are arranged in alphabetical order of families.

\begin{tabular}{|c|c|c|c|c|c|}
\hline Scientific name & Family & Group & Life form & Flowering season & Voucher No. \\
\hline Strobilanthes auriculata Nees & Acanthaceae & Eudicot & Shrub & Oct-Feb & PTndar211 \\
\hline Acorus calamus L. & Acoraceae & Monocot & Herb & Apr-Jul & PTndar003 \\
\hline Viburnum erubescens Wall. & Adoxaceae & Eudicot & Shrub & Apr-May & PTndar223 \\
\hline Viburnum mullaha Buch.-Ham. ex D. Don & Adoxaceae & Eudicot & Shrub & Jul-Sep & PTndar225 \\
\hline Sagittaria tengtsungensis $\mathrm{H} . \mathrm{Li}$ & Alismataceae & Monocot & Herb & May-Oct & PTndar192 \\
\hline Centella asiatica (L.) Urb. & Apiaceae & Eudicot & Herb & Mar-Apr & PTndar037 \\
\hline Oenanthe hookeri C.B. Clarke & Apiaceae & Eudicot & Herb & Jul-Sep & PTndar137 \\
\hline Oenanthe javanica (Blume) DC. & Apiaceae & Eudicot & Herb & Apr-Oct & PTndar138 \\
\hline Arisaema concinnum Schott & Araceae & Monocot & Herb & Apr-Jul & PTndar013 \\
\hline Arisaema flavum (Forssk.) Schott & Araceae & Monocot & Herb & Jun-Jul & PTndar014 \\
\hline Colocasia esculenta (L.) Schott & Araceae & Monocot & Herb & Jul-Sep & PTndar043 \\
\hline Hedera nepalensis K. Koch & Araliaceae & Eudicot & Liana & Oct-Nov & PTndar094 \\
\hline Hydrocotyle nepalensis Hook. & Araliaceae & Eudicot & Herb & May-Jul & PTndar098 \\
\hline Hydrocotyle sibthorpioides Lam. & Araliaceae & Eudicot & Herb & Mar-Apr & PTndar099 \\
\hline Schefflera roxburghii Gamble & Araliaceae & Eudicot & Liana & Apr-Jul & PTndar195 \\
\hline Ageratina adenophora (Spreng.) R.M. King \& H. Rob. & Asteraceae & Eudicot & Shrub & Jan-Jun & PTndar005 \\
\hline Ainsliaea latifolia (D. Don) Sch. Bip. & Asteraceae & Eudicot & Herb & Mar-Jun & PTndar008 \\
\hline Anaphalis margaritacea (L.) Benth. \& Hook. f. & Asteraceae & Eudicot & Herb & Jul-Dec & PTndar010 \\
\hline Artemisia indica Willd. & Asteraceae & Eudicot & Herb & Jul-Sep & PTndar015 \\
\hline Artemisia verlotiorum Lamotte & Asteraceae & Eudicot & Herb & Aug-Oct & PTndar016 \\
\hline Artemisia austroyunnanensis Y. Ling \& Y.-R. Ling & Asteraceae & Eudicot & Shrub & Aug-Oct & PTndar017 \\
\hline Aster neoelegans Grierson & Asteraceae & Eudicot & Herb & May-Sep & PTndar018 \\
\hline Cirsium falconeri (Hook. fil.) Petr. & Asteraceae & Eudicot & Herb & Jul-Oct & PTndar040 \\
\hline Crassocephalum crepidioides (Benth.) S. Moore & Asteraceae & Eudicot & Herb & Apr-Dec & PTndar048 \\
\hline Ixeridium beauverdianum (H. Lév.) Spring. & Asteraceae & Eudicot & Herb & Mar-Aug & PTndar112 \\
\hline Pseudognaphalium affine (D. Don) Anderb. & Asteraceae & Eudicot & Herb & Mar-Dec & PTndar166 \\
\hline Diplazium taiwanense Tagawa & Athyriaceae & Monilo & Herb & & PTndar059 \\
\hline Impatiens arguta Hook. f. \& Thomson & Balsaminaceae & Eudicot & Herb & May-Oct & PTndar107 \\
\hline Impatiens racemosa DC. & Balsaminaceae & Eudicot & Herb & May-Nov & PTndar108 \\
\hline Berberis aristata DC. & Berberidaceae & Eudicot & Shrub & Apr-May & PTndar020 \\
\hline Mahonia nepalensis DC. & Berberidaceae & Eudicot & Shrub & Apr & PTndar131 \\
\hline Alnus nepalensis D. Don & Betulaceae & Eudicot & Tree & Jul-Oct & PTndar009 \\
\hline Cynoglossum lanceolatum Forssk. & Boraginaceae & Eudicot & Herb & Year round & PTndar051 \\
\hline Cirriphyllum sp. & Brachytheciaceae & Moss & Herb & & PTndar039 \\
\hline Cardamine flexuosa With. & Brassicaceae & Eudicot & Herb & Jan-Jun & PTndar027 \\
\hline Nasturtium officinale W.T. Aiton & Brassicaceae & Eudicot & Herb & Jun & PTndar134 \\
\hline Rhodobryum giganteum (Schwägr.) Paris & Bryaceae & Moss & Herb & & PTndar174 \\
\hline Sarcococca hookeriana Baill. & Buxaceae & Eudicot & Shrub & Apr-Jun & PTndar194 \\
\hline Lobelia erectiuscula H.Hara & Campanulaceae & Eudicot & Herb & Jul-Sep & PTndar125 \\
\hline Cannabis sativa L. & Cannabaceae & Eudicot & Herb & Jun-Aug & PTndar026 \\
\hline Dipsacus inermis Wall. & Caprifoliaceae & Eudicot & Herb & Aug-Sep, Dec & PTndar060 \\
\hline Sagina japonica (Sw.) Ohwl & Caryophyllaceae & Eudicot & Herb & May-Jun & PTndar191 \\
\hline Stellaria reticulivena Hayata & Caryophyllaceae & Eudicot & Herb & Apr-May & PTndar210 \\
\hline Commelina diffusa Burm. f. & Commelinaceae & Monocot & Herb & Apr-Oct & PTndar044 \\
\hline Commelina paludosa Blume & Commelinaceae & Monocot & Herb & May-Nov & PTndar045 \\
\hline Cyanotis vaga (Lour.) Roem. \& Schult. & Commelinaceae & Monocot & Herb & Jun-Oct & PTndar049 \\
\hline Toricellia tiliifolia DC. & Cornaceae & Eudicot & Shrub & Apr-May & PTndar216 \\
\hline Carex condensata Nees & Cyperaceae & Monocot & Herb & Apr-Aug & PTndar028 \\
\hline Carex filicina Nees & Cyperaceae & Monocot & Herb & Apr-Aug & PTndar029 \\
\hline Carex capillacea Boott & Cyperaceae & Monocot & Herb & Apr-Jul & PTndar030 \\
\hline Carex diandra Schrank & Cyperaceae & Monocot & Herb & May-Jun & PTndar031 \\
\hline Carex rara Boott & Cyperaceae & Monocot & Herb & Apr-Jul & PTndar034 \\
\hline Carex rostrata Hoppe ex Schkuhr & Cyperaceae & Monocot & Herb & Apr-Aug & PTndar035 \\
\hline Carex setigera D. Don & Cyperaceae & Monocot & Herb & Apr & PTndar036 \\
\hline Fimbristylis ovata (Burm. f.) J. Kern & Cyperaceae & Monocot & Herb & Aug-Sep & PTndar079 \\
\hline
\end{tabular}


Table S2 Continued ...

\begin{tabular}{|c|c|c|c|c|c|}
\hline Scientific name & Family & Group & Life form & Flowering season & Voucher No. \\
\hline Pycreus flavidus (Retz.) T. Koyama & Cyperaceae & Monocot & Herb & Jun-Jul & PTndar169 \\
\hline Pycreus sanguinolentus (Vahl) Nees ex C.B. Clarke & Cyperaceae & Monocot & Herb & Jul-Sep & PTndar170 \\
\hline Schoenoplectus mucronatus (L.) Palla & Cyperaceae & Monocot & Herb & May-Jun & PTndar197 \\
\hline Scirpus wichurai Kom. & Cyperaceae & Monocot & Herb & Jul-Aug & PTndar198 \\
\hline Acystopteris sp. & Cystopteridaceae & Monilo & Herb & & PTndar004 \\
\hline $\begin{array}{l}\text { Daphniphyllum himalayense subsp. macropodum } \\
\text { (Miq.) T.C.Huang }\end{array}$ & Daphniphyllaceae & Eudicot & Shrub & Mar-May & PTndar055 \\
\hline Daphniphyllum himalense (Benth.) Mull.Arg. & Daphniphyllaceae & Eudicot & Tree & May-Sep & PTndar056 \\
\hline Hypolepis polypodioides (Blume) Hook. & Dennstaedtiaceae & Monilo & Herb & & PTndar106 \\
\hline Pteridium revolutum (Blume) Nakai & Dennstaedtiaceae & Monilo & Herb & & PTndar167 \\
\hline Dryopteris juxtaposita Christ & Dryopteridaceae & Monilo & Herb & & PTndar063 \\
\hline Dryopteris sp. & Dryopteridaceae & Monilo & Herb & & PTndar064 \\
\hline Dryopteris uniformis (Makino) Makino & Dryopteridaceae & Monilo & Herb & & PTndar066 \\
\hline Polystichum piceopaleaceum Tag. & Dryopteridaceae & Monilo & Herb & & PTndar157 \\
\hline Elaeagnus parvifolia Wall. ex Royle & Elaeagnaceae & Eudicot & Herb & Mar-Jun & PTndar067 \\
\hline Equisetum ramosissimum Desf. & Equisetaceae & Monilo & Herb & & PTndar073 \\
\hline Enkianthus deflexus (Griff.) C.K. Schneid. & Ericaceae & Eudicot & Shrub & May-Jun & PTndar070 \\
\hline Gaultheria semi-infera (C.B.Clarke) Airy Shaw & Ericaceae & Eudicot & Shrub & May-Jun & PTndar082 \\
\hline Gaultheria nummularioides D. Don & Ericaceae & Eudicot & Shrub & Aug-Sep & PTndar083 \\
\hline Leucothoe griffithiana C.B.Clarke & Ericaceae & Eudicot & Shrub & Jun-Aug & PTndar121 \\
\hline Lyonia ovalifolia (Wall.) Drude & Ericaceae & Eudicot & Shrub & May-Aug & PTndar127 \\
\hline Lyonia villosa (Wall. ex C.B. Clarke) Hand.-Mazz. & Ericaceae & Eudicot & Shrub & Jun-Aug & PTndar128 \\
\hline Pieris formosa (Wall.) D. Don & Ericaceae & Eudicot & Shrub & Feb-Jun & PTndar150 \\
\hline Rhododendron arboreum Sm. & Ericaceae & Eudicot & Shrub & Mar-Jun & PTndar175 \\
\hline $\begin{array}{l}\text { Rhododendron dalhousieae var. rhabdotum } \\
\text { (Balf. f.\& R.E. Cooper) Cullen }\end{array}$ & Ericaceae & Eudicot & Shrub & Apr-Jul & PTndar176 \\
\hline Rhododendron edgeworthii Hook. f. & Ericaceae & Eudicot & Shrub & Apr-May & PTndar177 \\
\hline Rhododendron lindleyi T. Moore & Ericaceae & Eudicot & Shrub & Apr-May & PTndar178 \\
\hline Rhododendron maddenii Hook. f. & Ericaceae & Eudicot & Shrub & May-Jul & PTndar179 \\
\hline Rhododendron triflorum Hook. $\mathrm{f}$. & Ericaceae & Eudicot & Shrub & Apr-Jun & PTndar180 \\
\hline Rhododendron virgatum Hook. $\mathrm{f}$. & Ericaceae & Eudicot & Shrub & Apr-May & PTndar181 \\
\hline Vaccinium dunalianum Wight & Ericaceae & Eudicot & Shrub & Apr-May & PTndar220 \\
\hline Vaccinium glaucoalbum Hook. f. ex C. B. Clarke & Ericaceae & Eudicot & Shrub & May-Jul & PTndar221 \\
\hline $\begin{array}{l}\text { Vaccinium retusum (Griff.) Hook. f. ex C. B. } \\
\text { Clarke }\end{array}$ & Ericaceae & Eudicot & Shrub & Apr-Jun & PTndar222 \\
\hline Eriocaulon viride Körn. & Eriocaulaceae & Monocot & Herb & Jul-Oct & PTndar074 \\
\hline Macaranga pustulata King ex Hook.f. & Euphorbiaceae & Eudicot & Tree & Nov-Mar & PTndar129 \\
\hline Parochetus communis Buch.-Ham. ex D. Don & Fabaceae & Eudicot & Herb & Mar-Sep & PTndar142 \\
\hline Trifolium repens $\mathrm{L}$. & Fabaceae & Eudicot & Herb & Apr-Jun & PTndar217 \\
\hline Quercus griffithii Hook.f. \& Thomson ex Miq. & Fagaceae & Eudicot & Tree & Apr & PTndar171 \\
\hline Gentiana cephalodes Edgew. & Gentianaceae & Eudicot & Herb & Aug-Oct & PTndar084 \\
\hline Gentiana capitata Buch.-Ham. ex D. Don & Gentianaceae & Eudicot & Herb & Feb-Jun & PTndar085 \\
\hline Gentiana maeulchanensis Franch. & Gentianaceae & Eudicot & Herb & Apr-Jun & PTndar086 \\
\hline Gentiana pedicellata (Wall. ex D. Don) Griseb. & Gentianaceae & Eudicot & Herb & Feb-May & PTndar087 \\
\hline $\begin{array}{l}\text { Halenia elliptica D. Don } \\
\text {. }\end{array}$ & Gentianaceae & Eudicot & Herb & May-Sep & PTndar093 \\
\hline $\begin{array}{l}\text { Swertia bimaculata (Siebold \& Zucc.) Hook. f. } \\
\text { \& Thomson ex C.B. Clarke }\end{array}$ & Gentianaceae & Eudicot & Herb & Jul-Oct & PTndar212 \\
\hline Geranium lambertii Sweet & Geraniaceae & Eudicot & Herb & Jul-Sep & PTndar088 \\
\hline Geranium procurrens Yeo & Geraniaceae & Eudicot & Herb & Jul-Sep & PTndar089 \\
\hline Gonocarpus micranthus Thunb. & Haloragaceae & Eudicot & Herb & Jul-Sep & PTndar092 \\
\hline Dichroa febrifuga lour. & Hydrangeaceae & Eudicot & Shrub & May-Nov & PTndar058 \\
\hline Hypericum gramineum G. Forst. & Hypericaceae & Eudicot & Herb & Jun-Aug & PTndar100 \\
\hline Hypericum hookerianum Wight \& Arn. & Hypericaceae & Eudicot & Shrub & Jun-Aug & PTndar101 \\
\hline $\begin{array}{l}\text { Hypericum petiolulatum Hook. f. \& Thomson } \\
\text { ex Dyer }\end{array}$ & Hypericaceae & Eudicot & Herb & Jul-Aug & PTndar103 \\
\hline Hypnum sp. & Hypnaceae & Moss & Herb & & PTndar104 \\
\hline gia $\mathrm{L}$. & Juglandaceae & Eudicot & Tree & Apr-May & PTndar114 \\
\hline Juncus bufonius $\mathrm{L}$. & Juncaceae & Monocot & Herb & Apr-Aug & PTndar115 \\
\hline Juncus inflexus L. & Juncaceae & Monocot & Herb & Apr-Aug & PTndar116 \\
\hline Juncus prismatocarpus $\mathrm{R}$. Br. & Juncaceae & Monocot & Herb & Apr-Aug & PTndar117 \\
\hline Luzula effusa Buchenau & Juncaceae & Monocot & Herb & May-Aug & PTndar126 \\
\hline Elsholtzia fruticosa (D. Don) Rehder & Lamiaceae & Eudicot & Shrub & Aug-Oct & PTndar069 \\
\hline Isodon hispidus (Benth.) Murata & Lamiaceae & Eudicot & Herb & Oct-Nov & PTndar110 \\
\hline Leucas ciliata Benth. & Lamiaceae & Eudicot & Herb & Jun-Oct & PTndar119 \\
\hline Phlomis macrophylla Benth. & Lamiaceae & Eudicot & Herb & Jul-Aug & PTndar149 \\
\hline Prunella vulgaris L. & Lamiaceae & Eudicot & Herb & May-Aug & PTndar165 \\
\hline Holboellia latifolia Wall. & Lardizabalaceae & Eudicot & Liana & Apr-Jun & PTndar096 \\
\hline Lindera pulcherrima (Nees) Hook. f. & Lauraceae & Magno & Shrub & Apr-Jun & PTndar124 \\
\hline Utricularia bifida L. & Lentibulariaceae & Eudicot & Herb & Jul-Sep & PTndar219 \\
\hline Scurrula elata (Edgew.) Danser & Loranthaceae & Eudicot & Shrub & Apr-Jun & PTndar199 \\
\hline Magnolia campbellii Hook.f. \& Thomson & Magnoliaceae & Magno & Tree & Mar-May & PTndar130 \\
\hline Leucolepis acanthoneura (Schwagr.) Lindb. & Mniaceae & Moss & Herb & & PTndar120 \\
\hline Jasminum humile L. & Oleaceae & Eudicot & Shrub & May-Jul & PTndar113 \\
\hline Ligustrum confusum Decne. & Oleaceae & Eudicot & Shrub & Apr-Jul & PTndar123 \\
\hline Oleandra undulata (Willd.) Ching & Oleandraceae & Monilo & Herb & & PTndar139 \\
\hline Epilobium sikkimense Hausskn. & Onagraceae & Eudicot & Herb & Jul-Sep & PTndar071 \\
\hline
\end{tabular}


Table S2 Continued ...

\begin{tabular}{|c|c|c|c|c|c|}
\hline Scientific name & Family & Group & Life form & Flowering season & Voucher No. \\
\hline Epilobium wallichianum Hausskn. & Onagraceae & Eudicot & Herb & Jul-Sep & PTndar072 \\
\hline Matteuccia struthiopteris (L.) Tod. & Onocleaceae & Monilo & Herb & PTndar133 & \\
\hline Bulbophyllum striatum (Griff.) Rchb. f. & Orchidaceae & Monocot & Herb & Oct-Nov & PTndar023 \\
\hline Calanthe griffithii Lindl. \& Paxton & Orchidaceae & Monocot & Herb & Apr-Jul & PTndar024 \\
\hline Coelogyne stricta (D. Don) Schltr. & Orchidaceae & Monocot & Herb & Mar-Jun, Oct-Nov & PTndar042 \\
\hline Cymbidium iridioides D. Don & Orchidaceae & Monocot & Herb & Oct-Nov & PTndar050 \\
\hline Dendrobium fimbriatum Hook. & Orchidaceae & Monocot & Herb & Mar-May & PTndar057 \\
\hline Pleione praecox (Sm.) D. Don & Orchidaceae & Monocot & Herb & Sep-Nov (Dec) & PTndar156 \\
\hline Spiranthes sinensis (Pers.) Ames & Orchidaceae & Monocot & Herb & Mar-Oct & PTndar209 \\
\hline Euphrasia bhutanica Pugsley & Orobanchaceae & Eudicot & Herb & May-Sep & PTndar076 \\
\hline Pedicularis gracilis subsp. stricta (Prain) P.C. Tsoong & Orobanchaceae & Eudicot & Herb & Jun-Sep & PTndar143 \\
\hline Osmunda japonica Thunb. & Osmundaceae & Monilo & Herb & & PTndar141 \\
\hline Tsuga dumosa (D. Don) Eichler & Pinaceae & Gymno & Tree & May-Jun & PTndar218 \\
\hline Piper suipigua Buch.-Ham. ex D. Don & Piperaceae & Magno & Liana & May-Aug & PTndar154 \\
\hline Ellisiophyllum pinnatum (Wall. Ex Benth.) Makino & Plantaginaceae & Eudicot & Herb & Apr-Aug & PTndar068 \\
\hline Plantago erosa Wall. & Plantaginaceae & Eudicot & Herb & Mar-Aug & PTndar155 \\
\hline Agrostis micrantha Steud. & Poaceae & Monocot & Herb & May-Nov & PTndar006 \\
\hline Agrostis zenkeri Trin. & Poaceae & Monocot & Herb & Sep-Oct & PTndar007 \\
\hline Brachypodium sp. & Poaceae & Monocot & Herb & Jun-Oct & PTndar021 \\
\hline Bromus hordeaceus $\mathrm{L}$. & Poaceae & Monocot & Herb & May-Jun & PTndar022 \\
\hline Festuca arundinacea Schreb. & Poaceae & Monocot & Herb & May-Sep & PTndar077 \\
\hline Festuca gigantea Krock. & Poaceae & Monocot & Herb & Jul-Sep & PTndar078 \\
\hline Isachne albens Trin. & Poaceae & Monocot & Herb & Jul-Feb & PTndar109 \\
\hline Saccharum sikkimense (Hook. f.) Nayaran ex Bor & Poaceae & Monocot & Herb & Jul-Jan & PTndar189 \\
\hline Thamnocalamus spathiflorus (Trin.) Munro & Poaceae & Monocot & Shrub & & PTndar215 \\
\hline Persicaria hydropiper (L.) Delarbre & Polygonaceae & Eudicot & Herb & Apr-Sep & PTndar145 \\
\hline Persicaria nepalensis (Meisn.) H. Gross & Polygonaceae & Eudicot & Herb & Apr-Oct & PTndar146 \\
\hline Persicaria perfoliata (L.) H. Gross & Polygonaceae & Eudicot & erb & May-Oct & PTndar147 \\
\hline Rumex nepalensis Spreng. & Polygonaceae & Eudicot & Herb & May-Jul & PTndar188 \\
\hline Drynaria parishii (Bedd.) Bedd. & Polypodiaceae & Monilo & Herb & & PTndar061 \\
\hline Drynaria propinqua (Wall. ex Mett.) Bedd & Polypodiaceae & Monilo & Herb & & PTndar062 \\
\hline Goniophlebium formosanum (Baker) Rodl-Linder & Polypodiaceae & Monilo & Herb & & PTndar091 \\
\hline Lepisorus thunbergianus (Kaulf.) Ching & Polypodiaceae & Monilo & Herb & & PTndar118 \\
\hline Potamogeton crispus L. & Potamogetonaceae & Monocot & Herb & Apr (-Jun) & PTndar158 \\
\hline Ardisia macrocarpa Wall. & Primulaceae & Eudicot & Shrub & May-Jul & PTndar012 \\
\hline Primula denticulata Sm. & Primulaceae & Eudicot & Herb & Feb-Jun & PTndar162 \\
\hline Prionodon sp. & Prionodontaceae & Moss & Herb & & PTndar164 \\
\hline Pteris wallichiana J. Agardh & Pteridaceae & Monilo & Herb & & PTndar168 \\
\hline Clematis montana Buch.-Ham. ex DC. & Ranunculaceae & Eudicot & Shrub & Apr-Jul & PTndar041 \\
\hline Ranunculus diffusus DC. & Ranunculaceae & Eudicot & Herb & Apr-Aug & PTndar173 \\
\hline Thalictrum foliolosum DC. & Ranunculaceae & Eudicot & Herb & Jun-Aug & PTndar214 \\
\hline Cotoneaster bacillaris Wall. ex Lindl. & Rosaceae & Eudicot & Tree & May-Jun & PTndar046 \\
\hline Fragaria nubicola (Hook. f.) Lindl. ex Lacaita & Rosaceae & Eudicot & Herb & Apr-Jun & PTndar080 \\
\hline Malus baccata (L.) Borkh. & Rosaceae & Eudicot & Shrub & Apr-May & PTndar132 \\
\hline Prinsepia utilis Royle & Rosaceae & Eudicot & Shrub & Mar-Apr & PTndar163 \\
\hline Rosa brunonii Lindl. & Rosaceae & Eudicot & Shrub & May-Jul & PTndar182 \\
\hline Rosa sericea Lindl. & Rosaceae & Eudicot & Shrub & Apr-Jun & PTndar183 \\
\hline Rubus biflorus Buch.-Ham. ex Sm. & Rosaceae & Eudicot & Shrub & May-Jul & PTndar185 \\
\hline Rubus ellipticus Sm. & Rosaceae & Eudicot & Liana & Feb-Apr & PTndar186 \\
\hline Rubus paniculatus Sm. & Rosaceae & Eudicot & Liana & Jun & PTndar187 \\
\hline Sorbus foliolosa (Wall.) Spach & Rosaceae & Eudicot & Tree & May-Jun & PTndar205 \\
\hline Sorbus thomsonii (King ex Hook.f.) Rehder & Rosaceae & Eudicot & Tree & Apr-May & PTndar206 \\
\hline Sorbus wallichii (Hook.f.) T.T. Yu & Rosaceae & Eudicot & Tree & Apr-May & PTndar207 \\
\hline Neanotis calycina (Wall. ex Hook. f.) W. H. Lewis & Rubiaceae & Eudicot & Herb & Jun-Sep & PTndar081 \\
\hline Galium aparine L. & Rubiaceae & Eudicot & Herb & Jul-Sep & PTndar135 \\
\hline Rubia wallichiana D & Rubiaceae & Eudicot & Herb & Apr-Sep & PTndar184 \\
\hline dium DC. & Rutaceae & Eudicot & Shrub & Oct-Feb & PTndar227 \\
\hline Salix stomatophora Flod. & Salicaceae & Eudicot & Shrub & Apr & PTndar193 \\
\hline Acer campbellii Hook.f. \& Thomson & Sapindaceae & Eudicot & Tree & Apr-May & PTndar001 \\
\hline Houttuynia cordata Thunb. & Saururaceae & Magno & Herb & Jun-Aug & PTndar097 \\
\hline Astilbe rivularis Buch.-Ham. ex D. Don & Saxifragaceae & Eudicot & Herb & Jul-Oct & PTndar019 \\
\hline Selaginella monospora Spring & Selaginellaceae & Monilo & Herb & & PTndar200 \\
\hline Selaginella helvetica (L.) Spring & Selaginellaceae & Monilo & Herb & & PTndar201 \\
\hline Selaginella remotifolia Spring & Selaginellaceae & Monilo & Herb & & PTndar202 \\
\hline Smilax perfoliata lour. & Smilacaceae & Monocot & Liana & Mar-Aug & PTndar203 \\
\hline Smilax myrtillus var. rigida Noltie & Smilacaceae & Monocot & Shrub & Sep-Oct & PTndar204 \\
\hline Sphagnum palustre L. & Sphagnaceae & Moss & Herb & & PTndar208 \\
\hline Taxus baccata L. & Taxaceae & Gymno & Tree & Mar-Apr & PTndar213 \\
\hline Daphne bholua Buch.-Ham. ex D. Don & Thymelaeaceae & Eudicot & Shrub & Feb-May & PTndar052 \\
\hline Daphne involucrata Wall. & Thymelaeaceae & Eudicot & Shrub & Nov-Feb & PTndar053 \\
\hline Girardinia diversifolia (Link) Friis & Urticaceae & Eudicot & Herb & Jul-Sep & PTndar090 \\
\hline Pilea symmeria Wedd. & Urticaceae & Eudicot & Herb & May-Jul & PTndar151 \\
\hline Pilea anisophylla (Hook. f.) Wedd. & Urticaceae & Eudicot & Herb & Apr-Jun & PTndar152 \\
\hline Pilea approximata C.B. Clarke & Urticaceae & Eudicot & Herb & Jun-Jul & PTndar153 \\
\hline Xyris capensis var. schoenoides (Mart.) Nilsson & Xyridaceae & Monocot & Herb & Jun-Sep & PTndar226 \\
\hline
\end{tabular}

